https://dx.doi.org/10.18778/7969-802-8.03

Adela Barabasz*

\title{
Relacja przełożony - podwładny w ujęciu psychoanalitycznym
}

\section{Wstęp}

Wiodącą rolę w każdej organizacji pełnią jej menedżerowie i liderzy, a jakość przywództwa jest uwarunkowana między innymi ich kompetencjami osobowościowymi. Oznacza to między innymi zdolność do rozumienia przyczyn zachowania podwładnych, współpracowników, zwierzchników, umiejętność trafnego wnioskowania interpersonalnego, a więc rozpoznawania motywów kierujących zachowaniem podwładnych oraz swoim własnym. Samoświadomość, w tym świadomość doświadczanych emocji, rozumienie relacji intrapsychicznych, interpsychicznych, wewnątrzgrupowych, międzyorganizacyjnych, to zagadnienia, które wydają się najistotniejsze z perspektywy psychologicznego spojrzenia na przywództwo.

Artykuł ma charakter teoretyczny. Jego podstawę teoretyczną stanowi psychoanalityczne rozumienie procesów zachodzących wewnątrz organizacji, ze szczególnym uwzględnieniem zjawiska przeniesienia (transference). Wykracza więc poza klasyczne teorie psychologii poznawczej, behawioralnej, psychologii społecznej, które najczęściej są wykorzystywane w naukach o organizacji i zarządzaniu. Artykuł powstał w oparciu o prace poświęcone problematyce przywództwa oraz osobowości liderów, z wykorzystaniem wyników obserwacji uczestniczącej.

Głównym celem artykułu jest zwrócenie uwagi na nieświadomy proces, jaki zachodzi w relacjach przełożony - podwładny, determinujący jakość wzajemnych stosunków, a w efekcie także efektywność funkcjonowania zespołów, grup i całych organizacji. Ze względu na nieświadomy charakter opisywanego zjawiska, jest on niedostępny bezpośredniemu poznaniu. Tym większe znaczenie ma w tej sytuacji przekazywanie wiedzy na temat zjawiska przeniesienia.

* Dr hab., profesor nadzwyczajny, Katedra Projektowania Systemów Zarządzania, Uniwersytet Ekonomiczny we Wrocławiu. 


\section{Podstawy psychodynamicznego podejścia do organizacji}

Zarówno teoretycy, jak i praktycy zarządzania poszukują prostych, jasnych oraz zrozumiałych, a jednocześnie uniwersalnych pojęć, które trafnie opisują wszelkie zjawiska psychospołeczne w organizacji. Potrzebują także skutecznych narzędzi pomiaru obserwowanych zachowań, zarówno w płaszczyźnie inter- jak i intrapsychicznej. W naukach o organizacji i zarządzaniu na przestrzeni lat pojawiają się liczne koncepcje, które proponują nowe widzenie istoty przywództwa. Paradygmat psychoanalityczny również proponuje własne rozumienie zjawisk organizacyjnych. Wynika ono z przyjęcia założenia o wpływie procesów nieświadomych na zachowania jednostek, uznania roli emocji na poziomie jednostek i grup, badanie mechanizmów obronnych oraz zjawiska przeniesienia w relacjach przełożony - podwładny.

Zgodnie z psychoanalitycznym paradygmatem człowiek staje się tym, kim jest dzięki przynależności do grup społecznych. Wszelkie doświadczenia gratyfikujące, ale też raniące i frustrujące, pojawiają się wskutek relacji z innymi ludźmi, tworzącymi kolejne grupy przynależności, od rodziców począwszy, poprzez klasę szkolną, grupę rówieśniczą na współpracownikach w miejscu pracy kończąc. Tradycję badania nieświadomych procesów i komunikacji w grupach i organizacjach zainicjowali członkowie Instytutu Tavistock, zainspirowani koncepcją M. Klein, a rozwiniętą przez W. Biona i innych przedstawicieli analizy grupowej. Przedstawiciele Tavistock Institute zakładają, że uwzględnienie doświadczeń emocjonalnych organizacji rzuca światło na wyzwania i dylematy, z jakimi zmaga się organizacja oraz ujawnia siły, które określają jej naturę. Zastosowanie zaś kleinowskiej koncepcji identyfikacji projekcyjnej daje wykładnię dla zrozumienia nieświadomej komunikacji, jaka odbywa się w grupach i organizacjach.

M. Kets de Vries i D. Miller (1984) dowodzą, że paradygmat psychoanalityczny pozwala na bogatsze, bardziej złożone i głębsze charakteryzowanie zachowań organizacyjnych aniżeli wyjaśnienia proponowane przez przedstawicieli innych nurtów badawczych. Odwołanie się do psychoanalizy, poprzez sięganie w głąb ludzkiej psychiki, umożliwia zrozumienie motywów ludzkich działań, zwraca uwagę na charakter relacji między członkami organizacji, wskazuje na mechanizmy wywołujące określone zachowania członków organizacji. To one właśnie, a nie jedynie indywidualne cechy jednostki, pozwalają zrozumieć złożone i zawiłe motywy ludzkich wyborów, doświadczanych lęków i nadziei (Barabasz 2012: 21-29).

Podstawowe założenie podejścia psychoanalitycznego mówi, iż zachowania uważane za racjonalne są $\mathrm{w}$ istocie uwarunkowane działaniem sił i mechanizmów znajdujących się poza poziomem świadomego poznania (zob.: Freud 2005; Freud 2009; Armstrong 2005; Gabriel 2004; Stapley 2013). By zrozumieć, co dzieje się w organizacji, należy więc nie tylko wznieść się ponad powierzchowną racjonalność, lecz także zmieniać ją poprzez wydobywanie na 
powierzchnię świadomości wypartych motywów, uczuć, pragnień i fantazji. D. Winnicott (1971), przedstawiciel nurtu relacji z obiektem uważa, że podstawą percepcji świata otaczającego jednostkę jest zbiór zinternalizowanych informacji dotyczących wyobrażeń o sobie, o świecie oraz o innych ludziach. Dzięki zdolności konstruowania abstrakcyjnych pojęć człowiek tworzy w swoim umyśle konstrukty, które dotyczą wszelkich obiektów ożywionych, jak i nieożywionych. Podobnie więc jak dziecko, które tworzy w swoim umyśle obraz matki, członkowie organizacji wytwarzają w swoich umysłach wyobrażenie organizacji (swojej firmy, przedsiębiorstwa), przypisując mu takie same atrybuty, jak każdemu znaczącemu obiektowi, z którym mieli do czynienia w swoim życiu. Mając taki „obraz” w swoim umyśle, działają tak, ,jak gdyby” istniał on realnie (zob.: Czander 1993; Hirschhorn 1997). Wpływa to ze szczególną siłą na charakter relacji z kluczowymi osobami w organizacji, w czym tkwi istota zjawiska przeniesienia.

Według M. F. Kets de Vriesa, L. Guillen, K. Korotowa, E. Florent-Treacy (2010: 29-30) paradygmat psychoanalityczny opiera się na następujących założeniach:

- to, co widzisz niekoniecznie jest tym, co widzisz;

- człowiek nie jest istotą racjonalną - irracjonalne zachowania są powszechne, także w organizacji, a może nawet tam częściej; podlegają one jednak silnej racjonalizacji;

- człowiek działa pod wpływem podstawowych potrzeb; tworzą one wewnętrzny świat, na który składają się trzy zasadnicze komponenty. Są to funkcje poznawcze, emocje oraz element behawioralny, czyli zachowanie;

- chcąc wpływać na zachowanie musimy brać pod uwagę zarówno sferę poznawczą, jak i emocje;

- wszyscy podwładni i przełożeni - mają „,ciemną stronę duszy”; wielu przywódców poniosło klęskę z powodu nieuwzględniania własnej osobowości, zwłaszcza lęków, zahamowań, iluzji na temat siebie, innych ludzi bądź świata zewnętrznego;

- każdy człowiek jest w pewnym stopniu bezradny wobec lęków i stosowanych przez siebie mechanizmów obronnych;

- jesteśmy „,produktami” własnej przeszłości - zostaliśmy ukształtowani przez otoczenie, w którym wychowywaliśmy się i żyjemy, jednak nieco zmodyfikowani przez wyposażenie genetyczne;

- z powodu niezwykle silnego naznaczenia tym, co dzieje się we wczesnych stadiach życia człowieka, mamy tendencję do powtarzania pewnych wzorców zachowań. Niezależnie od tego, czy nam się to podoba, czy nie, jest to być może najbardziej dosłowny wyraz związku między przeszłością a teraźniejszością. 
Zastosowanie paradygmatu psychoanalitycznego oznacza koncentrację na relacjach interpersonalnych, w które wchodzą członkowie organizacji, świadomie bądź nieświadomie. Paradygmat ten pomaga badać komplementarne role, jakie podejmują względem siebie członkowie zespołów zarządzających; pomaga identyfikować samoniszczące i samokarzące oczekiwania, przekonania oraz negatywną samoocenę, nieadekwatną autopercepcję, a także wzorce zachowań, które nawet jeśli w przeszłości były użyteczne, w aktualnej sytuacji są nieadekwatne i dysfunkcjonalne, a wiec „nieekonomiczne”. Paradygmat psychoanalityczny uwrażliwia więc na tendencje, zwłaszcza o charakterze dysfunkcjonalnym, które występują w zachowaniach osób znaczących dla organizacji, by następnie identyfikować je w zachowaniach pozostałych członków organizacji oraz zapobiegać rozprzestrzenianiu się ich negatywnych konsekwencji w całej organizacji.

Oczywiście, paradygmat psychoanalityczny, podobnie jak każdy inny, ma ograniczenia, które mogą powodować zniekształcenia w procesie badania organizacji. Podejściu psychoanalitycznemu najczęściej zarzuca się nadmierny subiektywizm oraz skłonność do koncentrowania się na nieprawidłowościach, zaburzeniach i patologicznych aspektach funkcjonowania organizacji. Skądinąd jednak wiadomo, że konsultanci, eksperci, trenerzy, doradcy, trafiają do organizacji właśnie wtedy, gdy jej funkcjonowanie w jakimś aspekcie szwankuje; są bowiem potrzebni wtedy, gdy pojawia się problem, którego członkowie organizacji nie potrafią samodzielnie i skutecznie rozwiązać.

\section{Rola menedżera - ujęcie psychodynamiczne}

W miejscu pracy zazwyczaj wykonuje się zadania wymagające nawiązywania relacji z innymi ludźmi - przełożonymi, podwładnymi, współpracownikami, klientami, kooperantami, itp. Sytuacje te uruchamiają mniej lub bardziej nieświadome potrzeby, budzą często silne emocje - lęk, złość, gniew, rozgoryczenie, ale także pasje i chęć działania, wzbudzają poczucie krzywdy lub wyższości, zawiść lub gotowość do poświęceń, itp. Środowisko społeczne organizacji może dostarczać satysfakcji i licznych gratyfikacji, ale też rozczarowań, poczucia krzywdy, dyskomfortu. Niezaspokojenie potrzeb i oczekiwań wywołuje zwykle frustrację, z wszelkimi jej konsekwencjami, w postaci agresji, regresji, fiksacji, a także innych niedojrzałych lub patologicznych reakcji dostosowawczych. Możliwość realizacji pragnień, potwierdzenie własnej skuteczności, doświadczanie rozwoju i poczucie spełnienia to także aspekty przynależności do organizacji.

H. S. Schwartz (1990) twierdzi, że organizacja doświadcza takich samych problemów, jakich doświadcza każdy podmiot ożywiony. Więź między członkami organizacji oraz ich zaangażowanie we wspólne działania to istotne aspekty jej funkcjonowania, decydujące o tym, że możemy widzieć organizację jako 
całość, a nie jedynie zbiór jednostek lub grup. Członkowie organizacji nawiązują relacje z innymi członkami organizacji, którzy postępując według tych samych reguł przyczyniają się do wzmacniania więzi grupowych i wewnątrzorganizacyjnych. Powstanie takich więzi skutkuje jednak wytworzeniem lęku przed utratą obiektów zaspokajających istotne potrzeby interpersonalne. W efekcie pojawia się lęk przed odrzuceniem i/lub utratą obiektów (Gutmann, Iarussi 2003). Przeżywanie tego typu obaw, niepokoju, a także lęku skłania do poszukiwania relacji z osobami, które będą chroniły, dawały poczucie bezpieczeństwa, wzmacniały nadzieję na lepsze jutro. Szczególnie predystynowani do pełnienia takiej roli są przełożeni (menedżerowie, kierownicy, liderzy).

Z perspektywy psychologicznej można uznać, że wpływ dominujących jednostek na pozostałych członków organizacji dokonuje się dzięki temu, iż przedstawiciele top managementu generują pewne wspólne wyobrażenia i wizje, które poprzez proces komunikacji i mechanizm naśladownictwa, przenikają do wszystkich poziomów organizacji. Ich treść jest przenoszona na wszystkie szczeble organizacyjnej struktury dzięki takim mechanizmom, jak identyfikacja i projekcja, ale szczególną rolę $\mathrm{w}$ tym procesie odgrywa zjawisko przeniesienia (transference). Poprzez te mechanizmy dochodzi do ukształtowania się dominującego w organizacji sposobu adaptacji do warunków otoczenia (zob.: Kernberg 1998; Stapley 1996; Barabasz 2008). To z kolei wpływa na styl podejmowania decyzji, zarówno na poziomie strategicznym, jak i operacyjnym. Dla celów organizacyjno-zarządczych zrozumienie relacji przeniesieniowych, którym mogą podlegać kluczowe osoby w organizacji nabiera szczególnego znaczenia. One bowiem są najbardziej pożądanymi obiektami uruchamiającymi nieświadomy proces przeniesienia u części członków organizacji.

\section{Przeniesienie - jako kluczowy aspekt relacji w organizacji}

Jednym z kluczowych zjawisk z punktu widzenia funkcjonowania każdej organizacji jest relacja przełożony - podwładny. W ramach tej relacji dochodzą do głosu nieświadome pragnienia i lęki, które w pewnych okolicznościach są wyprojektowywane na obiekt zewnętrzny w procesie przeniesienia, zazwyczaj zanim ukształtuje się realistyczna, dostosowana do zadania i wymogów roli relacja między członkiem organizacji a osobą znaczącą (przełożonym, liderem). S. Fhaner (1996: 194) definiuje przeniesienie jako „...proces nieświadomy, oznaczający, że uczucia, postawy, oczekiwania, pragnienia, itd., które wcześniej kierowały się w stronę ważnych w dzieciństwie osób, przenoszone są na inne obiekty... Zjawisko to jest uniwersalne i występuje w wielu codziennych relacjach między ludźmi. Przenosimy nieświadomie uczucia i postawy na osoby z naszego otoczenia, jak gdyby były to nowe wydania znaczących osób z naszego dzieciństwa". Według B. D. Moore’a i B. D. Fine’a (1996: 224-226) przeniesienie polega na 
„...przemieszczaniu wzorców myśli, zachowań i uczuć, pierwotnie przeżywanych w związku ze znaczącymi osobami w dzieciństwie, na jakąś osobę, z którą podmiot pozostaje $\mathrm{w}$ bieżącej relacji interpersonalnej... Zachodzący proces jest w znacznym stopniu nieświadomy..., a zjawisko przeniesienia pojawia się spontanicznie".

Członkowie organizacji zazwyczaj przekonani są, że w ich kontaktach ze współpracownikami istnieje jedynie relacja rzeczywista, która polega na świadomym przeżywaniu drugiej osoby w relacji taką, jaką ona jest w rzeczywistości. Relacja rzeczywista różni się od relacji przeniesieniowej, czyli nieświadomej projekcji postaw, jakie w dzieciństwie przyjmowaliśmy wobec osoby znaczącej (zwykle rodzica). W sytuacji przeniesienia nie tworzymy realnej relacji, ale dokonujemy projekcji własnych pragnień i potrzeb w osobę znaczącą (zazwyczaj jest nią przełożony, lider) i nieświadomie traktujemy tę osobę tak, jakby była kimś innym, czyli osobą z przeszłości (Stapley 2013: 106).

W przeniesieniu przywołujemy wszystkie uczucia, których doświadczaliśmy wobec ważnej osoby z przeszłości, np. członek organizacji może odczuwać wściekłość, zazdrość, wrogość wobec osoby, z którą aktualnie jest w relacji, chociaż sytuacja nie daje powodów do przeżywania tak silnych, negatywnych emocji. Może też doświadczać uczuć pozytywnych, np. podziwiać i adorować obiekt, oczekiwać wyjątkowego traktowania, wyrozumiałości i opieki. Zjawisko przeniesienia jest tym bardziej nasilone, im mniej dojrzała jest osoba, która tworzy relację przeniesieniowe. Ze względu na fakt, iż zjawisko przeniesienia ujawnia się szczególnie intensywnie w relacjach z osobami znaczącymi, podlegają im szczególnie często osoby sprawujące władzę w organizacji (formalną, ale też nieformalną). To na nich podwładni rzutują swoje pragnienia, które w przeszłości adresowali do osób znaczących w dzieciństwie. Odpowiedź na reakcję przeniesieniową nazywana jest przeciwprzeniesieniem i jest odpowiedzią obiektu (przełożonego) na emocjonalną treść zawartą w postawie, emocjach przeżywanych przez podwładnego. W. Czander i K. Eisold (2003) podkreślają, że przeniesienie i przeciwprzeniesienie towarzyszą wszystkim typom relacji.

Intensywne doświadczanie relacji przeniesieniowej stwarza znaczne trudności w budowaniu rzeczywistych relacji, sprzyjających realizacji zadań i celów organizacji. Jednakże zrozumienie przyczyn obserwowanych zachowań nacechowanych nieuzasadnionym ładunkiem emocjonalnym wymaga rozwiniętej samoświadomości oraz zdolności do autorefleksji, zarówno tej osoby, które zareagowała przeniesieniowe $\mathrm{w}$ relacji z przełożonym, jak i ze strony przełożonego jako obiektu przeniesienia. Zazwyczaj jednak nawiązujemy relacje $\mathrm{z}$ dobrze przystosowanymi osobami, które są świadome własnych zachowań oraz ich motywów i nie tracą kontaktu z rzeczywistością. Bez wątpienia w każdej organizacji zdarzają się jednak sytuacje które są efektem występowania intensywnego przeniesienia $w$ relacjach podwładnych z ich przełożonymi lub innymi osobami znaczącymi w organizacji. 


\section{Podsumowanie}

Psychoanalityczny paradygmat można uznać za podejście, dzięki któremu członkowie organizacji łatwiej mogą zreflektować własne zachowanie. Jego zastosowanie oczywiście nie dostarcza jednoznacznych odpowiedzi na wszystkie możliwe pytania, ale kategorie pojęciowe wypracowane przez psychoanalityków pozwalają na uporządkowanie wiedzy o społecznych i psychologicznych mechanizmach funkcjonowania organizacji. Przede wszystkim jednak dostarczają wglądu w zagadnienia doskonale znane menedżerom z ich praktyki, których inne koncepcje nie uwzględniają. Dotyczy to takich kwestii jak: rola emocji w organizacji, formy i funkcje mechanizmów obronnych, a przede wszystkim interpretowanie relacji przełożony - podwładny w oparciu o zjawisko przeniesienia.

Dojrzała relacja między przełożonym a podwładny jest jednym z czynników decydujących o powodzeniu organizacji w realizacji założonych celów. Jakość tej relacji w dużym stopniu zależy od rozpoznania zjawiska przeniesienia, które zachodzi na nieświadomym poziomie funkcjonowania grup i jednostek. Osoby bezpośrednio zaangażowane $\mathrm{w}$ relację nie są $\mathrm{w}$ stanie adekwatnie ją rozpoznać, gdyż podlegają zbyt silnej presji emocjonalnej o niezrozumiałym pochodzeniu. Konieczne jest w takiej sytuacji wsparcie osoby trzeciej. Może nim być doświadczony współpracownik, przełożony, mentor, coach lub inna osoba, pod warunkiem, że posiada niezbędną wiedzę, a jej zdolności rozpoznawania aspektów przeniesienia w relacji przełożony - podwładny nie zakłócają nieświadome potrzeby, wewnętrzne konflikty, ambiwalencja, itp. Kluczowym wyzwaniem dla przedstawicieli kadry zarządzającej, zwłaszcza tej części, która ma bezpośredni kontakt z pracownikami, jest więc świadomość własnego świata wewnętrznego - adekwatne rozpoznawanie nie tylko własnych atutów, umiejętności, zdolności, a także słabości, braków i ograniczeń. Oznacza to konieczność rozwijania zdolności do autorefleksji.

Badanie zachowań organizacyjnych oraz zjawisk związanych z funkcjonowaniem organizacji bez wiedzy i narzędzi, jakich dostarczają teorie psychoanalityczne, jest oczywiście możliwe. Ich brak pozbawia nas jednak możliwości zrozumienia zjawisk, zachodzących na poziomie funkcjonowania jednostek, grup i organizacji, które wymykają się bezpośredniemu poznaniu, gdyż ukryte są pod powierzchnią świadomego poznania. Psychoanalityczna perspektywa, choć niełatwa, pozwala tam właśnie sięgać. Rozpoznanie i zrozumienie nieświadomych treści wyrażanych $\mathrm{w}$ relacjach o charakterze przeniesieniowym jest warunkiem koniecznym, by mogła rozwinąć się relacja dojrzała, oparta na realistycznych wyobrażeniach, postawach i adekwatnych emocjach, wynikających z rzeczywistych, a nie nieświadomie wyprojektowanych emocjach. 


\section{BIBLIOGRAFIA}

Armstrong D. (2005), Organization in the Mind, Karnac, London.

Barabasz A. (2008), Osobowość organizacji. Zastosowanie w praktyce zarzqdzania, Wydawnictwo Uniwersytetu Ekonomicznego we Wrocławiu.

Barabasz A. (2012), Utajone życie organizacji - wyzwanie dla teorii i praktyki zarzadzania, „Contemporary Management Quarterly. The Journal of Scientific Community and Business Leaders", no. 4, p. 21-29.

Czander W. M. (1993), The Psychodynamics of work and Organizations. Theory and Application, Guilford Press, New York.

Czander W. M., Eisold K. (2003), Psychoanalytic perspectives on organizational consulting: Transference and Counter-transference, „Human Relation”, vol. 56(4), p. 475-490.

Freud Z. (2009), Psychologia nieświadomości, Wydawnictwo KR, Warszawa.

Freud Z. (2005), Psychologia zbiorowości i analiza ego, [w:] Poza zasada przyjemności, PWN, Warszawa.

Fhaner S. (1996), Stownik Psychoanalizy, GWP, Gdańsk.

Gabriel Y. (2004), Organization in the depth, Sage Publications, London.

Gutmann D., Iarussi O. (2003), Psychoanalysis and Management: The Transformation, Karnac Books, London.

Hirschhorn L. (1997), Reworking Authority: Leading and Following in the Post-Modern Organization, Organization Studies, Cambridge.

Kernberg O. (1998), Ideology, Conflict, and Leadership in Groups and Organizations, Yale University Press, New Haven.

Kets de Vries M. F. R., Miller D. (1984), The Neurotic Organization: Diagnosing and Changing Counterproductive Styles of Management, Jossey-Bass, San Francisco.

Kets de Vries M. F., Guillen L., Korotow K., Florent-Treacy E. (2010), The coaching kaleidoscope, Palgrave Macmillan, London.

Moore B. E., Fine B. D. (1996), Stownik psychoanalizy, Jacek Santorski \& Co Wydawnictwo, Warszawa.

Schwartz H. S. (1990), Narcissistic Process and Corporate Decay, New York University Press, New York, London.

Stapley L. (1996), The Personality of the Organization: A Psycho-Dynamic Explanation of Culture and Change, Free Association Books, London.

Stapley L. (2013), Ukryta dynamika, Oficyna Wolters Kluwer business, Warszawa.

Winnicott D. W. (1971), Playing and Reality, Tavistock Publications, London.

\section{Relation superior - employee in psychoanalytic perspective}

\section{SUMMARY}

An article introduces psychoanalytic concepts which can be of help in making sense of seemingly irrational processes in individuals, groups and organizations. Looking at an organization through the spectrum of psychoanalytic concepts is a potentially creative activity which may help in understanding and dealing with such issues like motivation, control, assessment of organizational members. An author believes that recognizing unconscious, hidden motives will let the managers to avoid automatic reactions and will improve the effectiveness of their influences. The main described notion is a transference occurring when employee brings into relationship with a superior 
(leader, manager) something that belongs elsewhere, which may take the form of a feeling, or a pressure to take up a particular role. Counter-transference is the response in the mind of superior, which may also take the form of a feeling or one kind of behavior. Both transference and countertransference are unconscious processes and are not liable to rational control. 